\title{
Implementation of Regional Regulation of Tabanan Regency Number 11 of 2018 Concerning Tourism Village Related to Increasing Investment Interest in Tabanan Regency
}

\author{
Ni Putu Santya Dewi ${ }^{1}$, I Nyoman Sujana ${ }^{2}$, I Wayan Wesna Astara ${ }^{3}$ \\ Master of Law Program, Universitas Warmadewa, Denpasar-Indonesia \\ Email: santyad@ymail.com
}

\begin{tabular}{|c|}
\hline Published: 30/09/2021 \\
\hline How to cite (in APA style): \\
\hline $\begin{array}{l}\text { Dewi, N. P. S., Sujana, I. N., \& Astara, I. W. W. (2021). Implementation of Regional Regulation of Tabanan Regency } \\
\text { Number } 11 \text { of } 2018 \text { Concerning Tourism Village Related to Increasing Investment Interest in Tabanan Regency. } \\
\text { Jurnal Hukum Prasada, 8(2), 116-121. doi: https://doi.org/10.22225/jhp.8.2.2021.116-121 }\end{array}$ \\
\hline
\end{tabular}

\begin{abstract}
Tourism that developed in Bali is an important sector for Tabanan Regency in increasing its tourism assets. Formation of Tabanan Regency Regulation No. 11 of 2018 concerning Tourism Villages is a legal umbrella that is expected to be able to increase investment interest in Tabanan Regency. The purpose of this study is to examine the regional regulation of Tabanan regency number 11 of 2018 concerning tourism villages related to increased investment interest in Tabanan regency and to examine the effectiveness of local regulation of Tabanan regency number 11 year 2018 regarding tourism villages related to increased investment interest in Tabanan regency. Furthermore, the method used in this study is empirical legal research method, meanwhile, a sociology approach is an approach used in this study. The results obtained from the study are that the implementation of Tabanan Regency Regulation Number 11 Year 2018 concerning Tourism Villages has been systematic, involving the role of regional apparatus and the community; and Tabanan Regency Regulation Number 11 Year 2018 regarding Tourism Villages related to increased investment interest has not been effective because there are still many obstacles and obstacles found.
\end{abstract}

Keyword: Investment; Regional Regulations; Tourism Village.

\section{INTRODUCTION}

Tourism is a leading sector to bring the country's foreign exchange to Indonesia because it is not only increasing income but also stimulating the growth of Indonesia's native culture so that culture can grow and continue to develop. Indonesia has so many tourism potentials that are spread throughout the region, with different characteristics with each region. One of the increasingly widespread tourism developments at this time is the tourist village. Village tourism as a component that is related presented into the structure of community territory so that it integrates with the procedures and traditions that apply.

The tourism village involves the local community, so culture is not only an object but also a tool for increasing investment in the area. Tabanan Regency is one of the provinces in Bali which also has so many excellent potentials in the field of tourism, including the Tourism Village. This awareness drives the formation of Tabanan Regency Regulation Number 11 Year 2018 concerning Tourism Villages. This regulation was made as a form of legal certainty in order to preserve nature and culture so that the development of tourism village potential can be well managed to improve the welfare of the people of Tabanan Regency, in addition to the establishment of regional regulations providing legal certainty guarantees for the Regional Government of Tabanan Regency in managing and 
determining the village area tour.

The development of a tourism village is a form of the mandate of Article 11 of the Law of the Republic of Indonesia Number 10 of 2009 concerning Tourism, which states that the Government together with institutions related to tourism are organizing tourism activities in support of tourism development. The tourism village in Tabanan Regency has a heterogeneous uniqueness but has the same goal, this is expected to encourage investment interest so that it affects not only the income of the tourism village in particular but also the Tabanan Regency in general.

There are several studies related to the development of tourist villages that have been carried out previously by several researchers. Irfan \& Suryani (2017) in their study conducted about Local Wisdom Based Tourist Village Organization in Lombok Tourist Area. The results of their study showed that the setup format Model of traditional Tourism tourism should Enhancing public participation, increase the length of stay of tourists, Cultural Preservation criteria must-have a typical Environment and customs, power Support Infrastructure, the availability of Land and Infrastructure, as well as the management and human resources and the critical role of Government. Moreover, a study conducted by Pakpahan (2019) that examined Tourist Legal Protection through Manado's Regional Regulation to Increase Tourism Level in Manado, showed that the enactment of the regulation is not followed by regular assessment which caused the lack of safety for tourist and unfair treatment towards international tourist. Although Perda No. 2/2015 and Perwali $15 / 2016$ has regulated the conduct of tourism business and protection, it still needs better enforcement regarding tourist protection through clearer implementation instruction, such as an independent body to foresee the legal obedience of the holder of tourism business license. Another similar study also conducted by Lubis et al. (2020) examined Strategy of Tourism Village Development Based on Local Wisdom. The results of their study revealed that the strategy of village development based on local wisdom is in the form of tourism in a tour package that includes batik schools, traditional Madurese games, and traditional art performances, regional culinary specialties, and lodging with the Tanean Lanjhang concept. Therefore, based on the previous studies above, it can be mentioned that there are many things that need to be considered in developing a tourist village, one of them is a strategy to increase tourists. In addition, the government's role is also important in the development of tourist villages, including implementing several regulations to increase investment interest in tourist villages. Based on the background and the previous studies above, the purpose of this study is to examine the regional regulation of Tabanan regency number 11 of 2018 concerning tourism villages related to increased investment interest in Tabanan regency and to examine the effectiveness of local regulation of Tabanan regency number 11 year 2018 regarding tourism villages related to increased investment interest in Tabanan regency.

\section{METHOD}

The type of research used in this study is empirical legal research, which is conducting observations or research directly to the field in order to get an accurate truth in the process of improving research writing (Efendi \& Ibrahim, 2018:149). The approach used is the legal sociology approach, with the discovery of facts, then identification, and finally, the problem solving (Aminuddin \& Asikin, 2006:20). Furthermore, after all the data obtained in the study and then it is continued with descriptive qualitative analysis.

\section{RESULT AND DISCUSSION}

\section{The Regional Regulation of Tabanan Regency Number 11 of 2018 Concerning Tourism Villages Related to Increased Investment Interest in Tabanan Regency}

Indonesia is a state of law whose source of government authority comes from laws and regulations, including the administration of rural tourism and investment. The 1945 Constitution of the Republic of Indonesia is the constitutional basis of all forms of legislation below, in accordance with the hierarchy of statutory provisions in Article 7 paragraph (1) of the Republic of Indonesia Law No. 12 of 2011 concerning the Formation of Legislation. 
Aside from being a law state, Indonesia is also a decentralized country, which means that government affairs consist of central government affairs and regional government affairs (Ridwan, 2011:17). This means that there are central government apparatus and regional government apparatus that are given autonomy, namely freedom and independence in regulating and managing their regional households.

Tabanan Regency Regulation Number 11 Year 2018 About Tourism Village is a form of authority of the Tabanan Regency Government in forming regulations relating to regional households, by implementing the mandate of the 1945 Constitution of the Republic of Indonesia and the Republic of Indonesia Law Number 10 of 2009 concerning Tourism. The existence of the legal substance regarding the laws and regulations is a strength and guidance that is owned to bind in the application of regional regulations so that the success of the policy can be achieved. Tabanan Regency Regulation Number 11 of 2018 concerning Tourism Villages as a natural and cultural preservation step in advancing general welfare for the people of Tabanan Regency through the development of tourism village potentials, so that the tourism potential they have can be managed well and provide benefits and benefits. In Article 1 number 7 of Regional Regulation of Tabanan Regency Number 11 of 2018 concerning Tourism Villages, it is stated that "Tourism villages are a form of integration between attractions, accommodation, and supporting facilities that are presented in a structure of community life that integrates with applicable procedures and traditions".

Tourism villages are formed without changing what already exists but tend to develop the potential of existing villages, by utilizing the capabilities of the elements in the village as attributes of tourism products on a small scale used as a series of tourism activities, and able to meet a series of travel needs both in terms of aspects attraction and supporting facilities (A.J, 2012:12). Village tourism that is packaged naturally and attractively will drive tourist visits to the tourist village so that economic activity can improve the welfare and empowerment of the community (Atmoko, 2014).

In implementing Tabanan Regency Regional Regulation Number 11 of 2018 concerning Tourism Villages, the regional apparatus not only plays a role in its formation, but also acts as a supervisor, implementer, and enforcer of the regulation. The Tabanan Regency Tourism Office and the One-Stop Integrated Investment and Licensing Services Office of Tabanan Regency are regional instruments related to the regional regulation. The Tabanan Regency Tourism Office has an important role from the process of declaration and determination of tourism villages, issuance of licenses, to supervision in collaboration with the Office of Investment and Integrated Licensing Services of the Tabanan Regency related to the issuance of permits related to tourism activities that affect investment in Tabanan Regency. In order to increase economic growth in Tabanan Regency, it is realized that to accelerate the development process a huge amount of funds is needed so that local governments are faced with a dilemma, therefore alternative sources of funding in the form of tourism potential can be utilized to realize the vision and mission of attracting investment interests both domestically and foreign. According to Article 1 of the Law of the Republic of Indonesia Number 25 Year 2007 concerning Investment, the definition of investment is "Investment is all forms of investment activities, both by domestic investment and foreign investors to do business in the territory of the Republic of Indonesia". The term investment is more popular in the business world, while the term investment is usually legislation, but basically the two terms have the same understanding. Investments can be done either individually, legal entities, or multinational companies. The development of a tourism village should be carefully planned with full planning so that the impacts that arise can be controlled, because the development of tourism potential in an area is expected to have many positive impacts but minimal negative impacts.

The Effectiveness of Local Regulation of Tabanan Regency Number 11 Year 2018
regarding Tourism Villages Related To Increased Investment Interest in Tabanan
Regency
This study used two theories as a legal knife in dissecting problems, because the This study used two theories as a legal knife in dissecting problems, because the
retical foundation is the basis for realizing the truth of legal science obtained from a 
series of studies on legal theory, legal concepts, legal principles, and others (Muhammad, 2004:73). The theory used is the Theory of Law Effectiveness and Theory of Utilization. According to Soerjono Soekanto, effective is the extent to which a group can achieve its goals. The law can be said to be effective if the law has a positive impact, so that it can achieve its goals in guiding and even changing human behavior into legal behavior (Soekanto, 1988:80). Meanwhile, according to Jeremy Bentham (Utilitarian Theory), the duty of law is to preserve well and prevent evil. With the intention, the law is to guarantee happiness for as many people as possible, and must be good so as not to disturb others even though the emphasis is on individual happiness, and the state and law are solely for true benefit (Aburaera et al., 2013:112).

Tabanan Regency has 22 tourist villages which in the development of each tourism village has a different rhythm and achievement. In this study, the destination tourist village is Jatiluwih Village, Timpag Village and Cau Village. The formation of local regulations regarding tourism villages as a form of nature and cultural preservation with the aim of developing village potential will improve welfare for the people of Tabanan Regency. In Article 5 of Regional Regulation of Tabanan Regency Number 11 Year 2018 Concerning Tourism Villages, "In the framework of developing regional tourism, the design and designation of tourist villages is compiled" which subsequently stipulates in Article 6, which involves regional apparatus, namely the manifestation of the role of the Regency Tourism Office Tabanan in it. The first tourism village in this study was Jatiluwih Village. Jatiluwih Village is located in Penebel District with an area of 2,233 Ha. Jatiluwih Village has so many natural and cultural potentials related to agricultural activities both pre-harvest to post -harvest that still use traditional tools. This well-preserved cultural authenticity is an added value so that it can attract tourists to travel. The second tourism village in this study is Timpag Village. Timpag Village is located in Kerambitan District with an area of $465 \mathrm{Ha}$. Timpag Village has tourism potentials reviewed from natural potential, cultural potential, and artificial potential. The potential is in the form of agricultural activities, Tyto Alba type of owl conservation, and Nangluk Merana cultural traditions, and the last village is Cau Village, located in Marga District, with an area of $414 \mathrm{Ha}$. Similar to Jatiluwih and Timpag Villages, Cau Village also has a lot of physical and tourism potential that is emphasized in topographical, geological and hydrological conditions. As well as the built potential, that is a form of community-made results.

Regulations on Tabanan Regency Regulation Number 11 Year 2018 Concerning Tourism Villages related to increased investment interest in Tabanan Regency, namely this regulation was made as a form of legal certainty and a manifestation of the seriousness of the Tabanan Regency Government in the effort to preserve all natural and cultural potential in Tabanan so that its utilization clear and good to be able to improve welfare in Tabanan Regency. Aside from being a guarantee of legal certainty for the government in the management of tourism villages, the existence of this regional regulation is also a legal umbrella in the implementation of investments carried out by both local and foreign investors, so that all activities can be well and clearly coordinated. The role of the Tabanan Regency Tourism Office is not only in the initial process of launching a tourism village, but also plays an important role in the field of issuance of licensing of all tourism business activities selectively so that the permit is appropriate and influences investment in Tabanan Regency. Not only that, the Tabanan Regency Tourism Office also plays other roles related to tourism villages such as coaching activities in the form of monitoring and evaluation, as these activities are carried out regularly at least 3 (three) months together with the manager of the tourist village.

In its management, the tourism village consists of several components, namely Accessibility, Accommodation, Attraction, Activities, and Amenities. Accessibility related to access to tourist attractions, Accomodation related to residential or overnight facilities, Attraction related to good attractions so that it is safe and worth visiting, Activities related to appropriate and safe tourism activities with existing potential, and Amenities which are facilities supporting tourism activities. In investment opportunities tailored to tourism villages, the increased investment interest is focused on Accessibility, Accommodation, and Amenities, as for attractions and activities as potentials in the development of existing 
tourist destinations, if these three factors are met then it will facilitate the entry of investment into Tabanan Regency.

In each Article which is divided into Chapters, the regulation of this regional regulation is so clear, that it is expected that its implementation and implementation can achieve the objectives of its formation. The development of a tourism village must be guided and supported by the community and its environment, because the community is fully involved in the process so that by respecting the rights of local communities so that sustainability is maintained. Associated with the theory of legal effectiveness and the theory of expediency, this regional regulation provides concrete benefits for the Regency of Tabanan, but it is still not effective on several factors, which are linked to investment opportunities.

The factors in question include legal substance, legal structure, legal culture, society, and facilities. One by one it was explained that the substance and legal structure of this regional regulation were clear and well implemented, but in several factors found various obstacles in the implementation of this regional regulation, both from its legal culture, society, and facilities. In connection with the legal culture of the tourist village which is highlighted as authenticity, there are several factors that are not in harmony with the law but are not a major obstacle. Then the community factor and facilities or facilities, it is undeniable that the influence of Human Resources influences a regional regulation, because in an area consists of various types and characters so that there are also traditional patterns in it which are a little slow in opening up to the entry of development. Related to facilities, this supporting factor also influences whether or not a local regulation is effective, it is also undeniable that even a facility is influenced by several factors both natural caused by disasters, and humans themselves such as lack of awareness in the management of both the community and visitors of the tourist village.

Achievement in the implementation of regional regulations is a joint success of various parties, because local regulations are made not only as an aspect of authority of the local government but also a form of community participation. Based on the data and long explanation above, it can be described as follows: Jatiluwih Village, Timpag Village, and Cau Village in the development of the tourism village have been based on Tabanan Regency Regulation Number 11 Year 2018 on Tourism Villages, with various other supporting factors so that the purpose of the regional regulations this can effectively provide benefits for Tabanan Regency. However, it is undeniable that the finding of the inhibiting factors mentioned earlier is constrained by the physical conditions of the three tourism villages above highlighting their natural potential as paddy fields, so it cannot be denied that problems related to natural disasters such as landslides also affect the potential maximization of tourism villages. Touched again about the inhibiting factors from humans, both from the local community of tourist areas and visitors to the tourist village who are lacking in the responsibility of environmental awareness is a shared obligation. Another inhibiting factor from the local community is the lack of capability and competence of the Human Resources; so that it tends to leave the village's potential by choosing other jobs, so that the human resources in the village with old age which in following its development is still slow.

\section{CONCLUSSION}

Based on the results and discussion that has been presented above, thus, it can be drawn the conclusion that arrangement for the implementation of Tabanan Regency Regulation Number 11 Year 2018 concerning Tourism Villages related to increased investment interest in Tabanan Regency as a reflection of Law of the Republic of Indonesia Number 10 Year 2009 Concerning Tourism. In addition this regional regulation as a form of nature and cultural preservation in Tabanan Regency in an effort to advance the welfare of the people of Tabanan Regency through the development of the tourism potential of each village by involving the role of regional apparatus of the Tabanan Regency Tourism Office and the Investment and Integrated Licensing Services Office of One Door Tabanan Regency is the executor and supervisor of the regional regulation. Furthermore, the implementation of Tabanan Regency Regulation Number 11 Year 2018 on Tourism Village has indeed provided benefits and is contained in the purpose of the formation of this 
regional regulation, but it is still not effective due to the inhibiting factors that arise even more from nature which cannot be avoided and the lack of awareness from the local community and tourists themselves.

\section{REFERENCES}

A. J, Mulyadi. (2012). Kepariwisataan dan Perjalanan. Jakarta: Raja Grafindo Persada.

Aburaera, S., Muhadar, \& Maskun. (2013). Filsafat Hukum: Teori dan Praktek. Jakarta: Prenadamedia Group.

Aminuddin, \& Asikin, Z. (2006). Pengantar Metode Penelitian Hukum (Cet. 1). Jakarta: Raja Grafindo Persada.

Atmoko, T. P. H. (2014). Strategi Pengembangan Potensi Desa Wisata Brajan Kabupaten Sleman. Jurnal Media Wisata, 12(2), 146-154. https://doi.org/https://doi.org/10.36276/mws.v12i2.87

Efendi, J., \& Ibrahim, J. (2018). Metode Penelitian Hukum Normatif dan Empiris. Jakarta: Prenada Media Group.

Irfan, M., \& Suryani, A. (2017). Local Wisdom Based Tourist Village Organization in Lombok Tourist Area. International Journal of English Literature and Social Sciences, 2(5), 73-82. https:// doi.org/10.24001/ijels.2.5.10

Lubis, H., Rohmatillah, N., \& Rahmatina, D. (2020). Strategy of Tourism Village Development Based on Local Wisdom. Jurnal IImu Sosial Dan Humaniora, 9(2), 320. https://doi.org/10.23887/jishundiksha.v9i2.22385

Muhammad, A. K. (2004). Hukum dan Penelitian Hukum. Bandung: PT. Citra Aditya Bakti.

Pakpahan, N. H. (2019). Tourist Legal Protection Through Manado's Regional Regulation to Increase Tourism Level in Manado. Journal of International Conference Proceedings, 2(2), 196-203. https://doi.org/10.32535/jicp.v2i2.619

Ridwan, H. (2011). Hukum Administrasi Negara. Jakarta: Rajawali Pers.

Soekanto, S. (1988). Efektivitas Hukum dan Penerapan Sanksi. Bandung: CV. Ramadja Karya.

UUD Negara Republik Indonesia Tahun 1945.

Undang-Undang Republik Indonesia Nomor 25 Tahun 2007 tentang Penanaman Modal.

Undang-Undang Republik Indonesia Nomor 10 Tahun 2009 tentang Kepariwisataan.

Undang-Undang Republik Indonesia Nomor 12 Tahun 2011 tentang Pembentukan Peraturan Perundang-undangan

Peraturan Daerah Kabupaten Tabanan Nomor 11 Tahun 2018 tentang Desa Wisata. 